\title{
Challenges with Implementation of the Merit System in the Open Recruitment of Government High Positions: The Case in Indonesia
}

\author{
Septiana Dwiputrianti, SE, M. Com (Hons), PhD \\ Indonesian Civil Service Commissioner (KASN) and NIPA RI \\ tiana.dwi@kasn.go.id
}

\begin{abstract}
Indonesia is a large country with the fourth highest population globally. Moreover Indonesia is estimated to become a high income country and be reckoned economically competitive with other countries by 2025 . However, bureaucratic governance and performance have not been able to put Indonesia in a strategic position to compete. This is due in part to the fact that the merit system has not yet been fully implemented. As an effort to reform and improve the performance of the public sector in Indonesia, the Indonesian Civil Service Commission (KASN) was established and given the authority to supervise and monitor implementation of the merit system. The KASN has, under this mandate, developed indicators to improve the bureaucratic system from a spoil system towards a merit system. This paper explores challenges with implementation of the merit system in the process of open recruitment, especially for government high positions in Indonesia. Moreover, this paper explains the factors that influence effectiveness with implementation of the merit system in open recruitment. Data was obtained from a number of ministries and local government agencies, using: government documents, official websites, media and other resources. There are three main results of the study, namely (1) indicators to assess implementation of the merit system in open recruitment, epecially for high positions in central and local governments; (2) challenges with implementing the merit system in open selection processes; (3) factors influencing implementation of the merit system in open recruitment.
\end{abstract}

Keywords: Open recruitment; Government high position; Merit system; Indonesia.

\section{Introduction}

To anticipate rapid global change, the government must build a more dynamic governance system. The Government of Indonesia (GOI) is putting effort into adapting policies to accelerate economic growth and to face uncertain global environmental changes. In achieving the objectives of the state to increase economic growth and welfare, to improve the quality of public services, and to provide more effective policy formulation and evaluation, Indonesia is giving more attention to the development of its human resources apparatus. This is especially aimed at providing bureaucratic leaders who are able to think ahead, and learn from other countries or organizations. The GOI has anticipated this problem by issuing Law Number 5 of the year 2014 on the Civil Service (UUASN) with the aim to realize a professional, neutral, and high integrity Civil Service (ASN) 
through implementation of a merit system in ASN policy and management. Implementation of the UU-ASN has provided a solid foundation for transforming management of the state civil apparatus from an administrative and rule based approach, towards performance based approach with human capital development implementation. This transformation is expected to improve the quality of public policy in order to encourage the development of the business world and the acceleration of economic growth. Enactment of the UU-ASN is expected to encourage the realization of excellent service to the society and the business world, increasing Indonesia's competitiveness globally, contributing to sustainable economic growth and avoiding Indonesia from the threat of the middleincome trap phenomenon.

Various international studies show that there is a positive correlation between the level of governance quality and the progress of a country, especially in the achievement of economic development and quality of life of the people. The quality of governance can be seen from various indicators or parameters, such as the Global Competitiveness Index, Ease of Doing Business (EODB), Government Effectiveness Index, and Corruption Perceptions Index (CPI). The progress of governance quality in the Indonesian government and its comparison with other ASEAN countries, is shown at Table 1.

\section{Table 1}

Quality Position of Governance, Comparing between Indonesia and ASEAN Countries

\begin{tabular}{|c|c|c|c|c|c|c|c|c|c|}
\hline \multirow[t]{2}{*}{ No } & \multirow[t]{2}{*}{ Country } & \multicolumn{2}{|c|}{$\begin{array}{c}\text { Global } \\
\text { Competitiveness } \\
\text { Index (GCI) } \\
2017 \text { - } 2018\end{array}$} & \multicolumn{2}{|c|}{$\begin{array}{c}\text { Ease Of Doing } \\
\text { Buisness } \\
\text { (EoDB) } \\
2017 \text { - 2018 }\end{array}$} & \multicolumn{2}{|c|}{$\begin{array}{c}\text { Corruption } \\
\text { Perceptions } \\
\text { Index } \\
\text { (2016) }\end{array}$} & \multicolumn{2}{|c|}{$\begin{array}{c}\text { Government } \\
\text { Effectiveness } \\
\text { Index } \\
(2016)\end{array}$} \\
\hline & & Rank & Score & Rank & Score & Rank & Score & Rank & Score \\
\hline 1 & Singapore & 3 & 5,71 & 2 & 84,57 & 7 & 84 & 1 & 100 \\
\hline 2 & Korea & 26 & 5,07 & 4 & 83,92 & 52 & 53 & 41 & 80,77 \\
\hline 3 & Malaysia & 23 & 5,17 & 25 & 78,43 & 55 & 49 & 51 & 75,96 \\
\hline 4 & Thailand & 32 & 4,72 & 26 & 77,44 & 101 & 35 & 71 & 66,35 \\
\hline 5 & Indonesia & 36 & 4,68 & 72 & 66,47 & 90 & 37 & 98 & 53,37 \\
\hline 6 & Vietnam & 55 & 4,36 & 68 & 67,93 & 113 & 33 & 99 & 52,88 \\
\hline 7 & Philippines & 56 & 4,35 & 113 & 58,74 & 101 & 35 & 101 & 51,92 \\
\hline
\end{tabular}

Source: World Bank, Global Governonce Index, Transparency International 2016-2017

Table 1 shows in terms of the quality of governance, Indonesia is still lagging behind other countries in ASEAN, especially Malaysia and Thailand. As is known, the quality of governance is strongly influenced by the management system and performance of the State Civil Apparatus (ASN).

Government efforts to realize an efficient, effective, and high-performance bureaucracy have shown results. This is evident from the World Economic Forum (WEF) report that Indonesia's competitiveness rating rose 5 (five) levels between 2016/2017 and 2017/2018. Nevertheless, the 
report still highlights some of the problems faced related to the ease of doing business in Indonesia: (i) corruption; (ii) bureaucratic inefficiency; (iii) availability of infrastructure. Based on these key issues, the Government of Indonesia is advised to prioritize corruption prevention efforts in various fields, particularly those related to business and investment development, and focus on implementing bureaucratic reforms to improve government bureaucracy inefficiencies, and improve infrastructure development.

In addition to the Competitiveness Index, one of the parameters used by the business community in making investment decisions is the Ease of Doing Business (EODB) index. Based on the EODB survey of 2017-2018 published by the World Bank, the ease of doing business in Indonesia rose from 91 to 72 , up 19 levels. This rating increase is a positive result achieved from various policy improvements and institutional arrangements by the bureaucracy including the civil state apparatus.

One indicator that reflects the performance of government bureaucracy is the government effectiveness index (Government Effectiveness). Assessment of government effectiveness is formulated from several parameters such as public perception on public service quality, public service quality and government independence from political pressure, quality of policy formulation and implementation, and government commitment in implementing policy. Effectiveness score of the Indonesian Government in 2016 and 2017 rose from 46 to 53, so that the ranking rose from 121 to 98 . To be able to catch up with other ASEAN countries, the Indonesian Government must continuously improve the quality of governance and build a professional civil state apparatus, integrity and high performance through acceleration of bureaucratic reform implementation.

As mandated by Law Number 5 Year 2014, Article 32 Paragraph (1) Point 'a', the KASN has the authority to supervise every stage of the process of filling the Position of High Leader (JPT) starting from the establishment of the institution selection committee, the announcement of vacancy, the selection process, the nomination of the candidate name, the determination and the inauguration of the Senior Chief Officer. Position of High Leader (JPT) is a group of high positions at government agencies consisting of JPT Utama, JPT Madya and JPT Pratama. The function of JPT positions is to lead and motivate every ASN employee in government agencies, through: (a) pioneering professional expertise, policy analysis and policy recommendations and leadership; (b) the development of cooperation with other agencies; and (c) exemplary behaviour in applying ASN basic values and implementing the ASN code of conduct. Implementation of open selection is intended to recruit candidates for bureaucratic leadership positions who have the competence, integrity and professionalism to improve the performance of bureaucratic organizations and support the implementation of governance and development, as the function mentioned above. 


\section{Literature review related with meritocracy and merit principle}

Everest-Phillips (2015: 94-98) argues that meritocracy can promote social mobility and can benefit individuals and society at large. He explores the case of Singapore that turned meritocracy into a development factor. It found that development is closely linked with building a civil service meritrocracy state and fostering public administration through motivation, promotion, the rule of law, integration, and non-tolerance of corruption. The author explains what benefits are caused by meritrokrasi and the impacts to humans and society. These arguments provide insight for those implementing merit systems as a means to provide the best service and reach their maximum potential. The author also gives examples of outcomes in countries that implement this meritcrasi system, such as its role in promoting higher economic growth, improving civil service performance and the performance of civil servants, accountability assessed by citizens, and a reduction in corruption. He also said that if Singapore wants to succeed then it must have a system that allows the best and most appropriate people to be in the jobs that need them. Since this merit principle has been applied, since 1965, Singapore has significantly increased per capita income. Lee Kuan Yew puts more emphasis on the success of his understanding of the need for good public administration in creating a clean, efficient, effective, and best of all public service ethos. Lee Kuan Yew instilled in public officials a sense of urgency and purpose, efficiency and impartiality, law and excellence in decision making, and zero tolerance for corruption. It is also important that meritrokrasi does not eliminate the need for transparency, accountability and rule of law.

In addition, Svensson and Wood (2009) examine the measurement of public sector organisations in Sweden in orders to communicate and implement code of ethics to public services. They employed a longitudinal survey approach. It concludes that public sector organizations in Sweden have few formal rules and regulations in place. The regulations related with code of ethics and code of conducts for employees encourage leaders and staff to behave correctly than pinpointing what to do or what not to do. Moreover, Tong, Jeffrey, and Walter (1999) emphasized an important element in reforming by applying a merit system in human resource management. This includes evaluating performance by rewarding employees and imposing sanctions on nonperforming employees. Open and fair competition in the selection and promotion process to assure the quality of government employees. In addition, the rules underpin the existence of sustainability and consistency in government policy. Building administrative and staffing professionalism is the biggest challenge. Problems such as abuse of authority, inefficiency, favoritism, excessive staffing, closeness, and corruption become intolerable. China has built a high quality of human resources and successfully pushed the country toward modernization and has a performance system that is quite effective. The principle of openness, justice, competition and selection to get the best employees is the process undertaken so far by China in carrying out administrative reform of bureaucracy in government.

Furthermore, Yoon and Kim (2016), emphasize the importance of different skill components based on the type of work employees. They are differentiate the skills of an employee both at the central and regional levels based on the aspects of prevention, preparedness, responding and improving things. Thus, these aspects become the focus of human resource management in 
the public sector, including in the process of selection or procurement of employees, education, training and performance management. While Ko and Walter (2013), states that Human Resource Management in practice has a significant contribution to organizational commitment, organizational behavior, and encourage the performance of the organization. The facts show that a working system based on high performance, is identified with the recruitment process is very selective, development and effective training, performance evaluation continuous, reward for fair performance, and decentralized decision-making is good with a promotions based on merit system.

Harel and Tzafir (2001) show out that the public sector has begun to move closer to a private sector model that adopts high performance-based work practices. This is as a result of the increasing demands and needs of the people on the performance of good bureaucratic services. Based on this, the selection process of employees and leaders in government becomes an absolute thing done in order to get professional human resources and can show high performance. Cho, et. al. (2013), remained the concept of bureaucracy Weber, where the application of the merit system in the selection process is done to encourage professionalism in the bureaucracy, highperformance, and comply with applicable regulations in comparison with the trend of political connections.

In Indonesia, merit system is the policy for management of all ASN based on qualifications, competencies and performance without distinction of political background, race, color, religion, origin, sex, marital status, age and disability conditions (Law Number 5/2014 about Civil Service, UUASN). Since the enactment of the UUASN in 2014, the implementation of a merit system in ASN management has become an obligation for all governments at the central and regional levels, and is evaluated by the State Civil Service Commission (KASN). Pardede and Mustam (2017), examine the management of ASN in Semarang regency. Based on the results of their study, they emphasize the importance of human resources in public sector organizations. Chassamboulli and Gomes (2017) underline how important recruitment policy and incentive is in public sector organizations. However, they found that some state recruitment and government payments did not follow meritocracy practices. The meaning of the merit system in Government Regulation Number 11 Year 2017 about the management of civil servants, subsection 134, paragraph 2, covers the criteria of implementation of selection and promotion is to be open; and implementation of the code of ethics and code of conduct of ASN Employees.

The purpose of applying the merit system in open selection is to be able to recruit professional high integrity ASNs and place them in government bureaucratic posts according to their competence; maintain ASN through fair and reasonable compensation; develop ASN capability through guidance and training; and protect ASN careers from politicization and policies that go against the merit principle (neptism, primordialism, etc.). KASN serves to oversee the implementation of basic norms, code of conducts and code of ethics and also to implement the Merit System in ASN policies and Management of Government Agencies (subsection 30 ASN Law).

Why should open selection become more popular than the application of merit systems in other aspects of ASN management? This is because the open selection is a quick win for merit 
system implementation and aims to get the right people according to the needs of the organization. Another thing that is not less important is that open selection can also overcome the spoil system and the sale and purchase of positions and increase the mobility of ASN.

\section{Research methodology}

This research uses descriptive qualitative research method. Sources of data for this study are primary data obtained from interviews with resource persons and informants. Data analysis is done by data reduction, data presentation and conclusion. Primary data was obtained from interviews with high officials from Ministries and Local Government agencies, and secondary data from government laws and documents, the KASN website, printed and virtual medias and other resources. There are three main results of the study, namely (1) effectiveness of the open selection process of high officials in Indonesia (2) government commitment and leaders' accountability to their organisation to pursue some targets and outputs through implementation of merit principles; and (3) external and internal supports and other great challenges to applying the merit system in open selection processes.

\section{Discussion about challenges implementation of merit system in open recruitment of government high position}

The ASN Law mandates open and competitive filling of Positions of Leadership (JPT) among Civil Servants with respect to qualifications, competence, rank, education and training, job track record, and integrity and other job requirements in accordance with the provisions in legislation. The aim is to get the right people in positions in the government bureaucracy to improve the performance and effectiveness of governance and development. The policy of filling JPT positions through open selection has changed the paradigm in ASN management. Prior to the ASN Law, the approach to filling positions in the government bureaucracy was a closed career system oriented to seniority and rank. With the enactment of the ASN Act, the approach is changed towards an open career system that prioritizes competition and ASN competence. This change in approach is to encourage ASN employees to continue to increase their capacity.

In addition, the adoption of open selection is also intended to address political interventions in the appointment, transfer and dismissal of ASN employees. Historically, civil service management has started with spoil system where the position is associated with political affiliation. Positions are also traded as commodities. The practice of buying and selling positions leads to the low quality of high-ranking officials in the bureaucracy and this becomes an obstacle to the realization of an efficient and effective Indonesian bureaucracy. The transactional costs of positions in the civil service could be estimated to achieve $\mathrm{Rp} 35$ trillion per year. The practice of transactional costs at the local government is not a new phenomenon, especially in local government agencies that have very low levels of compliance in implementing the ASN Law. Corruption in the regions, which starts from the election process is very expensive. The placement of officials in positions strategic to the planning and implementation of development make the 
agenda of improving public services, improving the quality of human resources, and efforts to encourage the improvement of public welfare difficult to achieve. President Joko Widodo highlighted the practice of buying and selling positions in the management of civil state apparatus (ASN) during a limited meeting on ASN management. He gave a reminder that this practice should be eliminated and eradicated completely.

In order to fill high leadership positions (JPT) through open and competitive selection implemented pursuant to the principle of merit, Article 32 Paragraph (1) Sub-Paragraph 'a' of Law Number 5 Year 2014 on State Civil Apparatus authorizes the State Civil Service Commission (KASN) to oversee each stage of the process of filling the position of the Higher Leader starting from the establishment of the selection committee of the institution, announcement vacancy, selection implementation, nomination of candidate names, determination, and inauguration of Senior Officials.

In conducting supervision on the filling of JPT Position, in accordance with the provisions of Article 120 paragraph (3) and paragraph (4) of Law Number 5 of 2014, the State Civil Service Commission (KASN) has the authority to give its recommendation to the officer responsible for the selection decision. The process of the implementation in the supervision of open selection, is outlined in the Table 2 below.

Table 2

KASN Recommendations on JPT Open Selection t Government Agencies 2015 - 2017

\begin{tabular}{|c|c|c|c|c|c|c|c|c|c|c|c|c|c|}
\hline \multirow[b]{2}{*}{ No } & \multirow[b]{2}{*}{ Agency } & \multicolumn{3}{|c|}{ Total } & \multicolumn{3}{|c|}{ Approval } & \multicolumn{3}{|c|}{ Improvements } & \multicolumn{3}{|c|}{ Cancellation } \\
\hline & & 2015 & $\begin{array}{c}201 \\
6\end{array}$ & 2017 & 2015 & 2016 & 2017 & 2015 & $\begin{array}{c}201 \\
6\end{array}$ & $\begin{array}{c}201 \\
7\end{array}$ & $\begin{array}{c}201 \\
5\end{array}$ & 2016 & $\begin{array}{c}201 \\
7\end{array}$ \\
\hline 1 & $\begin{array}{l}\text { Ministry / } \\
\text { Institution }\end{array}$ & 181 & 195 & 55 & 117 & 127 & 47 & 64 & 64 & 8 & - & 4 & 0 \\
\hline 2 & $\begin{array}{l}\text { Provincial } \\
\text { government }\end{array}$ & 53 & 54 & 57 & 34 & 39 & 20 & 17 & 11 & 20 & 2 & 4 & 17 \\
\hline 3 & $\begin{array}{l}\text { District / } \\
\text { City } \\
\text { Government }\end{array}$ & 365 & 482 & 406 & 233 & 355 & 291 & 108 & 79 & 90 & 24 & 48 & 25 \\
\hline & Total & 599 & 731 & 518 & 384 & 521 & 358 & 189 & 154 & 118 & 26 & 56 & 42 \\
\hline
\end{tabular}

Source: State Civil Service Commission (KASN), 2018.

To anticipate rapid global change, the government must build a more dynamic governance system and adapt its policies to rapid and uncertain global environmental changes so that the objectives of the state can still be realized. In order to strengthen the process and integration for filling Positions of Leadership (JPT) in government institutions, KASN has launched the Application of High Leadership Selection (SIJAPTI). The application covers the entire selection process, from consultation, submission of selection plan documents and reports of selection results, 
to JPT database documentation. The SIJAPTI application was developed in order to support the government movement towards an e-governance system, so that the selection process of high positions at both national and regional levels become faster and cheaper. On October 4, 2017, SIJAPTI was launched at the office of the Ministry of Administrative Reform and Bureaucracy Reform (PAN-RB) together with 7 (seven) other e-government development innovations. The egovernment innovation is to realize the agile, effective and efficient government bureaucracy. This is necessary given the development of technology and information that has affected and triggered a very revolutionary change in the order of human life. The launching of the SIJAPTI was attended by Coordinating Minister for Political, Legal and Security Affairs (Menko Polhukam), PAN-RB Minister and Heads of LPNK and Secretary General / Secretary of Ministries / Institutions and Provincial Secretaries throughout Indonesia.

Diagram 1: Stages of Selection of High Leadership Positions (JPT)

\section{PREPARATION}

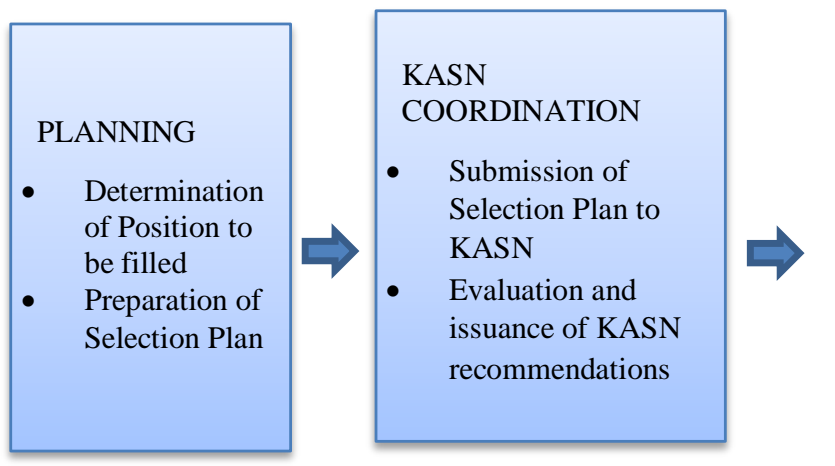

\section{IMPLEMENTATION}

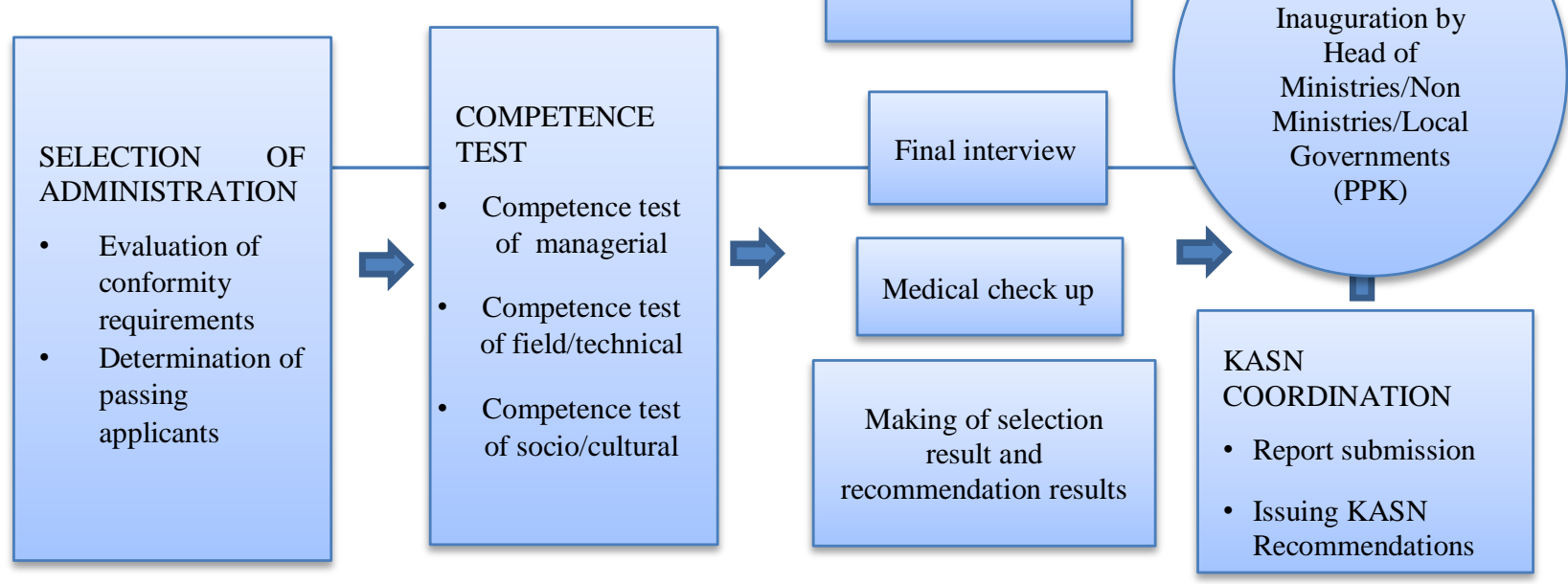

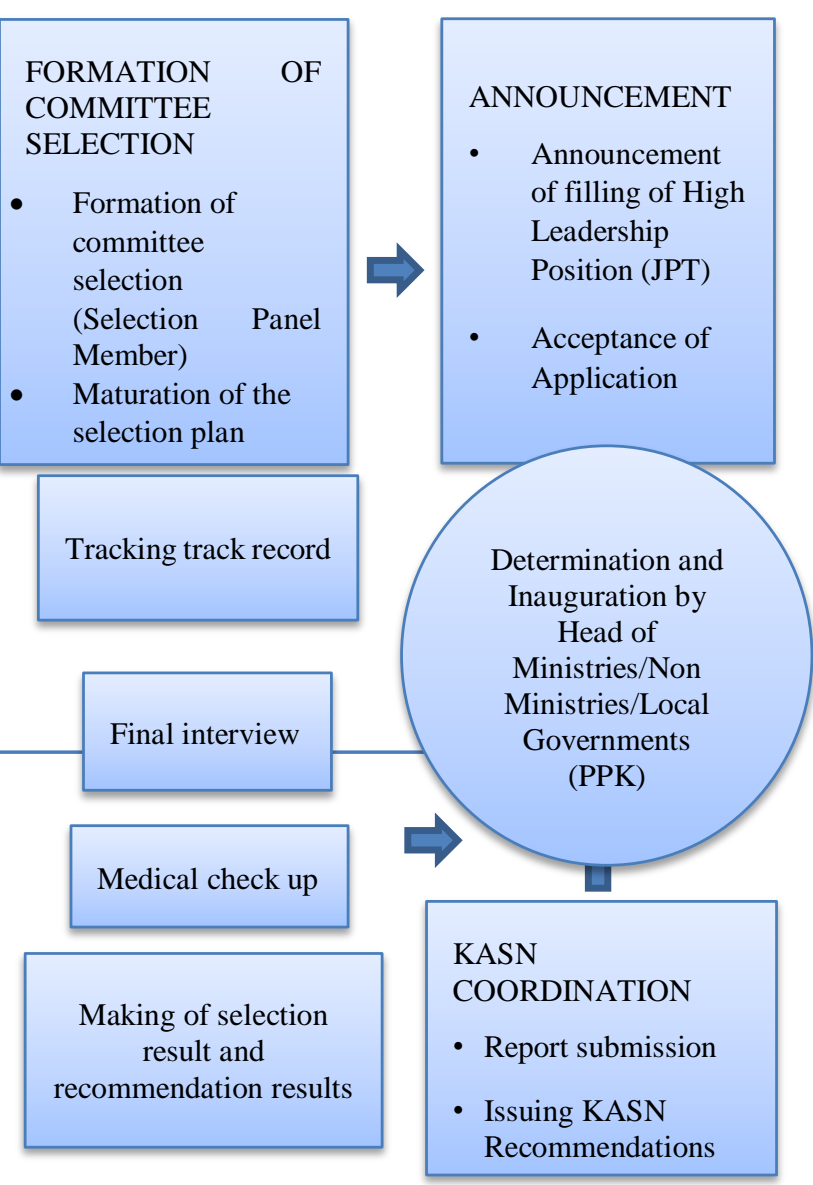

Currently all Ministries, Non-Ministry Government Institutions, Provincial Governments and almost all District / City Governments have conducted an open selection in the filling of JPT. However, the result of KASN evaluation shows that the quality of governance of selection still varies. There are still agencies whose implementation of the selection has not been fully compliant. 
In relation thereto, KASN has compiled the KASN Regulation on the Preparation and Implementation Procedure of Filling the JPT in order to provide a reference for institutions in preparing and conducting selections. In addition, KASN also establishes the KASN Regulation on the code of conduct and the conduct of the selection committee.

Although almost all agencies have conducted open selections, there are still a number of agencies that do open selection that does not fully comply with the provisions, and some are still recruiting JPT but not through open selection. In addition there are still Officers Civil Service officers who dismiss officials from office for reasons that are less strong and not through reprimand procedures, summoning and investigation as regulated in Government Regulation No. 53 of 2010 on the Discipline of civil servants and Government Regulation Number 46 of 2011 on the Appraisal of Civil Service Performance

Based on KASN's experience in supervising the implementation of Law No. 5 of 2014 on State Civil Apparatus, there are still some problems or obstacles in implementing the policy. First obstacle is lack of preparedness of the institution to carry out the open selection. This is due to a number of reasons, such as: (1) not having compiled the job descriptions, qualifications and standard of competence of the existing high leadership position, (2) not conducting performance appraisal in accordance with the provisions, and (3) not having employee competency profile data so that the implementation of open selection at the government agency takes time for preparation;

Second obstacle is a limited number of certified assessment centers or assessors. The number of performance assessment agencies (recorded center) in the State Personnel Agency (BKN) in 2016 was as few as 20 institutions and 210 assessors. This amount is very small compared to the need for assessment centers to conduct competency testing in the next few year, for filling around 30,585 JPT positions in 34 Ministries, 31 Non-Ministry Government Institutions (LPNK), 89 Non-Structural Institutions (LNS), 34 Provinces and 514 Districts and Cities in Indonesia.

Third problem is the limited selection of competent, credible and non-political or independent committee members has the potential to create a conflict of interest given the close bonds of the fraternity in the region. The credibility of the selection committee can also be disrupted by political intervention by the Civil Service Officers (PPK), political parties, nongovernmental organizations or other parties. Conflict of interest is still found in some of the selection committee selection results in various government agencies both central and local.

Fourth obstacle is the reluctance of civil servants to compete and the fear that the merit principle is not actually implemented due to their experience that appointments and dismissals in office are often based on reasons unrelated to the merit system. Moreover, fifth problem is that the Law of ASN is still patchy, while waiting for the issuance of government regulations to support its implementation. Government regulation of the implementation of Law No. 8 of 1974 and Law Number 43 Year 1999 are still enacted and this creates problems from different interpretations in the implementation of ASN management. 
The sixth problem is the weak performance management system in government institutions in the implementation of the merit system, such as the consistent implementation of Government Regulation Number 46 Year 2011 on the Rating of Civil Servant Performance. Seventhly, strong political intervention in ASN management means there are still appointments and dismissals of JPT officials not based on the merit principle. There are still Personnel Officers (PPK) who want to maintain the spoil system, where the appointment of Senior Chief Officer (PPT) is not based on the aspects of competence, qualification and professionalism through open selection. Similarly with the dismissal of officials of the JPT, which is often carried out without strong grounds and procedures as stipulated in the Act.

The last problem is the filling of structural positions especially the position of senior management (JPT) in the new regional apparatus organization (PPP) as the implementation of PP No. 18 of 2016 on regional apparatus has not been entirely based on the qualification, competence, and organizational needs.

\section{References}

Chassamboulli, A dan Gomes, P. (2017). Jobs for the boys! Meritocracy, public sector pay and human capital accumulation. University of Cyprus and Universidad Carlos III de Madrid.

Cho, Wonhyuk, et. al. (2013). A cross-country study of the relationship between weberian bureaucracy and government performance. International Review of Public Administration, 18 (3), 115-137.

Government of Indonesia Law (UU) Number 5 of the Year 2014 on Civil Service

Government of Indonesia Regulation (PP) Number 11 of the year 2017 on Civil Service Management.

Harel, Gedaliahu H and Tzafrir, Shay S. (2001). HRM practices in the public and private sectors: Differences and similarities. Public Administration Quarterly, 25 (3/4), 316-350.

Ko, Jaekwon and Walter, Aaron Smith. (2013). The relationship between HRM practices and organization performance in the public sector: Focusing on mediating roles of work attitudes. International Review of Public Administration, 18(3) 299-231.

Ministerial Regulation of PANRB (PermenPANRB) Number 13 of the year 2014 on the Procedures for Filling the Position of High Leadership at Government Institutions.

Meyrina, Susana. (2016). Implementasi peningkatan kinerja melalui merit sistem guna melaksankan Undang-Undang Aparatur Sipil Negara No. 5 tahun 2014 di Kementrian Hukum dan HAM (implementation of performance improvement through merit system in utilizing the act on civil state apparatus number 5 year 2014 at the ministry of law and human rights). Jurnal Ilmiah Kebijakan Hukum, 10(2), 175-185.

Pardede, A.C. and Mustam, M. (2017). Manajemen sumber daya manusia pegawai negeri sipil dalam rangka reformasi birokrasi di kabupaten Semarang. Semarang: Universitas Diponegoro.

Perry, James L. (1986). Merit pay in the public sector: The case for a failutre of theory. Review of Public Personnel Administration, 7(1), 51-69. 
Philips and Everest. (2015). Meritocracy and public service excellent. International Journal of Civil Service Reform and Practice, (5), 94-98

Svensson, Goran and Wood, Greg. (2009). Inculcating the ethos of public-sector codes of ethics in sweden: a longitudinal approach. Corporate Governance, 9(2), 175-188.

Tong, Caroline Haiyan, Jeffrey D, Straussman and Walter D, Broadnax. (1999). Civil service reform in the people's Republic of China: Case studies of early implementation. Public Administration \& Development, 19, 193-206.

Yoon, Kun and Kim, Chulwoo. (2016). Components of expertise of public officials in emergency management in Korea: An exploratory study. International Review of Public Administration, 21(1), 37-56. 